PERM JOURNAL OF PETROLEUM AND MINING ENGINEERING

ВЕСТНИК ПНИПУ. ГЕОЛОГИЯ. НЕФТЕГАЗОВОЕ И ГОРНОЕ ДЕ

ISSN 2224-9923

Volume/ Toм 16 №3 2017

http://vestnik-pstu.ru/geo/

УДК 622.257.12:519.24

Article / Статья

(C) PNRPU / ПНИПУ, 2017

\title{
STATISTICAL MODELLING OF EXPANDING CEMENT SLURRY
}

\section{Vladislav I. Galkin, Artem A. Kunitskikh}

Perm National Research Polytechnic University (29 Komsomolskiy av., Perm, 614990, Russian Federation)

\section{СТАТИСТИЧЕСКОЕ МОДЕЛИРОВАНИЕ РАСШИРЯЮЩЕГОСЯ ТАМПОНАЖНОГО СОСТАВА}

\section{В.И. Галкин, А.А. Куницких}

Пермский национальный исследовательский политехнический университет (614990, Россия, г. Пермь, Комсомольский пр., 29)

Received / Получена: 28.06.2017. Accepted / Принята: 10.07.2017. Published / Опубликована: 15.09.2017

Key words:

expanding cement slurry, regression analysis, correlation analysis, mathematical model, well, expanding additives.

\begin{abstract}
Questions of statistical processing of results of laboratory studies of expanding cement slurry are considered. Calcium oxide with inhibitors of a hydration reaction and calcium oxide with dicalcium ferrite are used as expansion additives. Six types of expansion additives are tested. Studies are performed at the two temperature regimes such as 22 and $75{ }^{\circ} \mathrm{C}$. Series of results is obtained. At the first stage of mathematical processing of data evaluation of differences in mean values of linear expansion values by the Student's criterion were estimated. Comparison of mean values by certain options showed that maximum influence of temperature among studied parameters belongs to $\mathrm{CaO}+$ ferrochrome lignosulfonate (FCLS) (99/1), minimum influence belongs to $\mathrm{CaCO}_{3}+\mathrm{FeSO}_{4}(2: 1)$. To consider joint influence of concentration of the expanding additive and temperature on the value of linear expansion multidimensional models are built. Model values of linear expansion were calculated from multidimensional models and then compared with experimental values. Comparisons are made in two ways. The first way is based on the total number of all the data. The second way is based on six models built on different additives. As a result, two correlation fields are obtained. Each filed has three subfields (classes). Distinguished classes are described by linear discriminant functions with help of linear discriminant analysis. An analysis of obtained discriminant functions showed that values of linear expansion in classes are formed in accordance with different mechanisms. Therefore, refined multidimensional models and linear discriminant functions are built to calculate the values of linear expansion with three distinguished classes considered. A performed analysis showed that values of linear expansion in the range of 1-6 \% are formed depending on concentration of the additive and temperature. Then in the range of 6-10\% the process proceeds due to a synergistic effect of the joint influence of concentration of an additive and temperature.
\end{abstract}

Рассмотрены вопросы статистической обработки результатов лабораторных исследований расширяющегося тампонажного состава. В качестве расширяющей добавки использовался оксид кальция с ингибиторами реакции гидратации и оксид кальция с двухкальциевым ферритом. Всего испытано шесть вариантов расширяющих добавок. Исследования проводились при двух температурных режимах: 22 и $75{ }^{\circ} \mathrm{C}$. В результате получили выборку результатов. На первом этапе математической обработки данных произведена оценка различий средних значений величин линейного расширения по критерию Стьюдента. Сравнение средних значений по отдельным вариантам показало, что максимальное влияние температуры по изучаемым показателям получено для СаO + феррохромлигносульфонат (ФХЛС) (99/1), минимальное - по $\mathrm{CaCO}_{3}+\mathrm{FeSO}_{4}(2: 1)$. Для учета совместного влияния концентрации расширяющей добавки и температуры на величину линейного расширения построены многомерные модели. По многомерным моделям были вычислены модельные значения линейного расширения, и далее они были сопоставлены с экспериментальными значениями. Сопоставления выполнены по двум вариантам: первый вариант - по совокупности всех данных, второй вариант - по шести моделям, построенным по разным добавкам. В результате получены два корреляционных поля, на каждом из которых выделяются три подполя (класса). C помощью линейного дискриминантного анализа выделенные классы описываются линейными дискриминантными функциями. Анализ полученных дискриминантных функций показал, что процессы формирования значений линейного расширения в классах происходят по различным механизмам, поэтому построены уточненные многомерные модели и линейные дискриминантные функции для вычисления значений линейного расширения с учетом выделенных трех классов. Выполненный анализ показал, что формирование значений линейного расширения в диапазоне 1-6\% происходит в зависимости от концентрации добавки и температуры, далее в интервале 6-10\% процесс протекает за счет синергетического эффекта совместного влияния концентрации добавки и температуры.

Vladislav I. Galkin (Author ID in Scopus: 55418067700) - Doctor of Geology and Mineralogy, Professor, Head of the Department of Oil and Gas Geology (tel.: +007 342219 80 17, e-mail: vgalkin@pstu.ru).

Artem A. Kunitskikh - PhD in Engineering, Senior Lecturer at the Department of Oil and Gas Technologies (tel.: +007 342 219 82 07, e-mail: artem_kunitskikh@mail.ru). The contact person.

Галкин Владислав Игнатьевич - доктор геолого-минералогических наук, профессор, заведующий кафедрой геологии нефти и газа (тел.: +007 3422198017 , e-mail: vgalkin@pstu.ru).

Куницких Артем Александрович - кандидат технических наук, старший преподаватель кафедры нефтегазовых технологий (тел.: +007 3422198207 , e-mail: artem_kunitskikh@mail.ru). Контактное лицо для переписки. 


\section{Introduction}

Today there are two third of world's production fluid is water and only one third of oil. That causes the necessity of additional costs for well operation and utilization of produced water [1].

One of the factors that causes increase in water cut of production fluid is a breach of cement stone sealing $[2,3]$. Poor quality of well cement stone also leads to appearance of intercolumn pressure, griffins and interlayer flows [4-6].

There is no universal set of methods that could ensure high well cement stone integrity using nowadays cementing technology [7]. Considerable role is given to cement material that fills a well annulus $[8,9]$.

Density of a contact between cement stone, casing and rocks is largely dependent on its volumetric changes during hardening [10, 11]. In order to improve operational characteristics of cement slurries they are modified by mineral and polymer additives. An inportant role among that additives belongs to expanding ones [12]. Volumetric expansion of cement stone significantly increases tightness of a contact between cement stone and adjacent media.

\section{Analytical review of expanding additives}

Currently, there is no ready-made expanding slurries produced on the plants that produce cementing portland cement. As a result, production of expanding cements is possible only by preparing dry mixtures directly on a field.

Development of an expanding cement slurry for existing mining and geological conditions provides selection of an optimal expansion mechanism, type of an expanding additive base, required expansion and matching of expansion dynamics with dynamics of a cement stone strengthening $[13,14]$.

There are two main ways to obtain an expanding cement slurry. According to the first method, there is a compound formed inside the structure of a cement stone which has a larger volume than the original one. The second way is to increase the volume of cement by gassing [15].

In most cases, it is difficult to control kinetics of gas formation. Gas is released prior to the placement of a cement slurry at the specified annulus interval. In addition, gas will pass from the free state to the dissolved state at sufficiently high pressures. In accordance with the mentioned well cementing method these factors inhibit use of expanding cement slurries [16].
According to the first method an expanding cement slurry is obtained by adding the following additives into the sement slurry [17-19]:

- chromate sludge, additive concentration is $25-30 \%$;

- caustic magnesite, concentration of additive $10-15 \%$;

- bischofite, bischofite solution with density of $1320 \mathrm{~kg} / \mathrm{m}^{3}$;

- sodium chloride and calcium chloride, the concentration of the additive is $5-15 \%$;

- mixture of gypsum and alumina cement in the ratio of gypsum: alumina $=1: 2$, application of ready-to-use gypsum-alumina cement, concentration of additive is $20-30 \%$;

- sodium sulfate, concentration of an additive is $5 \%$;

- high-calcium ash of Heating and Power Plant, concentration of an additive is $20-30 \%$;

- alumina, concentration of additive is $1-3 \%$;

- aluminum polyoxychloride (APXH), concentration of an additive is $1-3 \%$;

- quicklime, concentration of an additive is $3-10 \%$;

- alunite ore, concentration of an additive is $10-30 \%$;

- a mixture of calcium oxide and ferrite, concentration of an additive is 3-10\%.

The most widely used as an expanding additive is quicklime (calcium oxide). Introduction of calcium oxide in an amount of 2-10\% with respect to cement allows obtaining volumetric expansion up to $20 \%$ and more [20-22]. However, hydration of calcium oxide in most cases ends before formation of cement stone, i.e. expansion energy does not increase internal stresses [23].

There are inhibitors of hydration of calcium oxide distinguished such as condensed sulfite alcohol spent wash of KSSB-2M brand, copper vitriol, sodium liquid glass, ferrochrome lignosulfonate of FHLS-MN brand, sodium silicate of Atrem Light, anhydrite, G-5 gypsum, sodium tripolyphosphate, naphthalene formaldehyde plasticizer [24]. Results of experimental studies of the effect of these agents on time of hydration of calcium oxide were sampled. Results of sampling showed that the most promising are KSSB-2M, FHLS-MN, Atren Light.

Binding of calcium oxide in minerals could be an alternative to calcium hydration inhibitors. A positive effect on an expansion value of simultaneous input of calcium oxide and dicalcium ferrite into sement slurry is determined [25]. Hydration form calcium hydroxide and calcium hydroperfrit that form together a four-calcium hydroliferite. 


\section{Analysis of the effect of calcium oxide and ferrite on a cement stone}

Effect of addition of calcium oxide with modifying components and calcium oxide with dicalcium ferrite on volume deformations of cement stone was comared in the laboratory of drilling and cement slurries according to appropriate studies (Tables 1 and 2). An additive of calcium oxide with dicalcium ferrite was obtained by joint calcination at $1100{ }^{\circ} \mathrm{C}$ of limestone and ferrous sulphate at various weight ratios [24-26].

Study of formation and quantification of the magnitude of linear expansion depending on the content of calcium oxide with inhibitors (options 1-3) and with two-calcium ferrite (options 4-6) after 48 hours at temperatures of 22 and $75{ }^{\circ} \mathrm{C}$ are performed using statistical methods. To compare the magnitude of linear expansion for these options we estimate the differences in the mean values using $t$-criterion taking into account the concentrations (Table 3). To do this, values of t-criterion are calculated by the following formula:

$$
t_{\mathrm{p}}=\frac{\left|X_{1}-X_{2}\right|}{\sqrt{\frac{1}{n_{1}}+\frac{1}{n_{2}}\left(\frac{\left(n_{1}-1\right) S_{1}^{2}+\left(n_{2}-1\right) S_{2}^{2}}{n_{1}+n_{2}-2}\right)}},
$$

where $X_{1}, X_{2}$ are mean values of indexes of the sample; $S_{1}{ }^{2}, S_{2}{ }^{2}$ are variance of sample indexes. Difference in mean values is considered statistically significant if $t_{\mathrm{p}}>t_{t}$, where $t_{\mathrm{p}}$ is calculated criterion value and $t_{t}$ is tabular value of the criterion $t$. Values $t_{t}$ are determined depending on the amount of data being compared and the level of significance $(\alpha=0.05)$. Comparison of the studied indexes is given in the Table 3 .

Table 1

Dependence of linear expansion from the content of calcium oxide with inhibitors (after 48 hours at temperatures of 22 and $75^{\circ} \mathrm{C}$ )

\begin{tabular}{|c|c|c|c|c|c|c|}
\hline \multirow{2}{*}{$\begin{array}{c}\text { Concentr } \\
\text { ation, } \%\end{array}$} & \multicolumn{2}{|c|}{$\begin{array}{c}\mathrm{CaO}+\mathrm{KSSB} \\
(97 / 3)\end{array}$} & \multicolumn{2}{c|}{$\begin{array}{c}\mathrm{CaO}+\mathrm{FHLS} \\
(99 / 1)\end{array}$} & \multicolumn{2}{c|}{$\begin{array}{c}\mathrm{CaO}+\text { Atren } \\
\mathrm{Light}(98 / 2)\end{array}$} \\
\cline { 2 - 7 } & $\begin{array}{c}2{ }^{\circ} \mathrm{C} / \\
48 \mathrm{~h}\end{array}$ & $\begin{array}{c}75^{\circ} \mathrm{C} / \\
48 \mathrm{~h}\end{array}$ & $\begin{array}{c}22^{\circ} \mathrm{C} / \\
48 \mathrm{~h}\end{array}$ & $\begin{array}{c}75^{\circ} \mathrm{C} / \\
48 \mathrm{~h}\end{array}$ & $\begin{array}{c}22^{\circ} \mathrm{C} / \\
48 \mathrm{~h}\end{array}$ & $\begin{array}{c}75^{\circ} \mathrm{C} / \\
48 \mathrm{~h}\end{array}$ \\
\hline 0 & 0 & 0 & 0 & 0 & 0 & 0 \\
\hline 3 & 4.6 & 1.8 & 3.2 & 1 & 5.2 & 2 \\
\hline 5 & 9.3 & 2.8 & 8.8 & 1.8 & 7.5 & 3.3 \\
\hline 8 & 23.2 & 4.5 & 15.5 & 2.2 & 19.5 & 5.5 \\
\hline
\end{tabular}

Note. KSSB is a condensed sulfite alcohol spent wash; FHLS is a ferrochrome lignosulfonate; Atren Light is a sodium metasilicate.
Table 2

Dependence of linear expansion of calcium oxide content with dicalcium ferrite (after $48 \mathrm{~h}$ at temperatures of 22 and $75^{\circ} \mathrm{C}$ )

\begin{tabular}{|c|c|c|c|c|c|c|}
\hline \multirow{2}{*}{$\begin{array}{c}\text { Concentr } \\
\text { ation, \% }\end{array}$} & \multicolumn{2}{|c|}{$\begin{array}{c}\mathrm{CaCO}_{3}+\mathrm{FeSO}_{4} \\
(2: 1)\end{array}$} & \multicolumn{2}{|c|}{$\begin{array}{c}\mathrm{CaCO}_{3}+\mathrm{FeSO}_{4} \\
(4: 1)\end{array}$} & \multicolumn{2}{c|}{$\begin{array}{c}\mathrm{CaCO}_{3}+\mathrm{FeSO}_{4} \\
(8: 1)\end{array}$} \\
\hline & $\begin{array}{c}22 \mathrm{C} / \\
4\end{array}$ & $\begin{array}{c}75^{\circ} \mathrm{C} / \\
48 \mathrm{~h}\end{array}$ & $\begin{array}{c}2{ }^{\circ} \mathrm{C} / \\
48 \mathrm{~h}\end{array}$ & $\begin{array}{c}75^{\circ} \mathrm{C} / \\
48 \mathrm{~h}\end{array}$ & $\begin{array}{c}2{ }^{\circ} \mathrm{C} / \\
48 \mathrm{~h}\end{array}$ & $\begin{array}{c}75^{\circ} \mathrm{C} / \\
48 \mathrm{~h}\end{array}$ \\
\hline 0 & 0 & 0 & 0 & 0 & 0 & 0 \\
\hline 1 & 0.2 & 0.06 & 1.1 & 0.1 & 1.4 & 0.1 \\
\hline 3 & 2.9 & 1.3 & 3.1 & 1 & 4.3 & 0.6 \\
\hline 5 & 6.3 & 3.3 & 6.7 & 3.1 & 8.5 & 2.6 \\
\hline 8 & 14.3 & 6.2 & 15.5 & 5.9 & 16.6 & 5 \\
\hline
\end{tabular}

Table 3

Comparison of mean values of linear expansion

\begin{tabular}{|c|c|c|c|}
\hline \multirow[t]{2}{*}{ Parameters } & \multicolumn{2}{|c|}{$\begin{array}{l}\text { Mean values } \\
\text { of indexes, \% }\end{array}$} & \multirow{2}{*}{$\begin{array}{l}\text { Statistical } \\
\text { estimates of } \\
\text { Student } t_{\mathrm{p}}\end{array}$} \\
\hline & $22^{\circ} \mathrm{C}$ & $75^{\circ} \mathrm{C}$ & \\
\hline All data & $6.58 \pm 6.75$ & $2.006 \pm 2.01$ & $\frac{3.375113}{0.001402}$ \\
\hline $\mathrm{CaO}+\mathrm{KSSB}(97 / 3)$ & $9.27 \pm 10.02$ & $2.27 \pm 1.88$ & $\begin{array}{l}1.371901 \\
0.219178 \\
\end{array}$ \\
\hline $\mathrm{CaO}+\mathrm{FHLS}(99 / 1)$ & $6.87 \pm 6.80$ & $1.25 \pm 0.97$ & $\begin{array}{l}1.636937 \\
0.152758\end{array}$ \\
\hline $\mathrm{CaO}+$ Atren light $(98 / 2)$ & $8.05 \pm 8.25$ & $1.24 \pm 2.31$ & $\begin{array}{l}1.248611 \\
0.258317 \\
\end{array}$ \\
\hline $\mathrm{CaCO}_{3}+\mathrm{FeSO}_{4}(2: 1)$ & $4.74 \pm 5.92$ & $2.17 \pm 2.61$ & $\begin{array}{l}0.886763 \\
0.401077 \\
\end{array}$ \\
\hline $\mathrm{CaCO}_{3}+\mathrm{FeSO}_{4}(4: 1)$ & $5.28 \pm 6.25$ & $2.02 \pm 2.50$ & $\begin{array}{l}1.081881 \\
0.310835 \\
\end{array}$ \\
\hline $\mathrm{CaCO}_{3}+\mathrm{FeSO}_{4}(8: 1)$ & $6.16 \pm 6.68$ & $1.66 \pm 2.14$ & $\begin{array}{l}1.434242 \\
0.189413 \\
\end{array}$ \\
\hline
\end{tabular}

That shows at temperature of $22{ }^{\circ} \mathrm{C}$ mean values of linear expansion $\left(P_{l}\right)$ are much higher than at temperature of $75{ }^{\circ} \mathrm{C}$ for all options. It should be noted that mean values of $P_{l}$ are statistically different only using data on total amount of all the studied options. Comparison of mean values on some options showed that the maximum effect of temperature on parameters studied was obtained for $\mathrm{CaO}+$ FHLS (99/1), minimum on $\mathrm{CaCO}_{3}+\mathrm{FeSO}_{4}(2: 1)$. Changes in linear expansion $\left(P_{l}\right)$ for the options studied as a function of temperature $t$ and concentration $\mathrm{C}$ are shown in Fig. 1.

Based on that it is clear that for $t=22{ }^{\circ} \mathrm{C}$ if values of $C$ change, the value of $P_{l}$ increases more intensively than for $t=75{ }^{\circ} \mathrm{C}$. To account the combined influence of the values of $C$ and $t$ on $P$ value we construct multidimensional models. That allows estimating the "contribution" of influence of the indexes on $P_{l}$ options. Multidimensional models are constructed using step-by-step regression analysis. Calculation of regression coefficients in the developed models is performed using the least 
squares method. Regression analysis is understood as a statistical method of investigation of dependencies between the dependent variable $Y$ and one or more independent variables $X_{1}, X_{2}, \ldots, X_{p}$. A dependent attribute in a regression analysis is
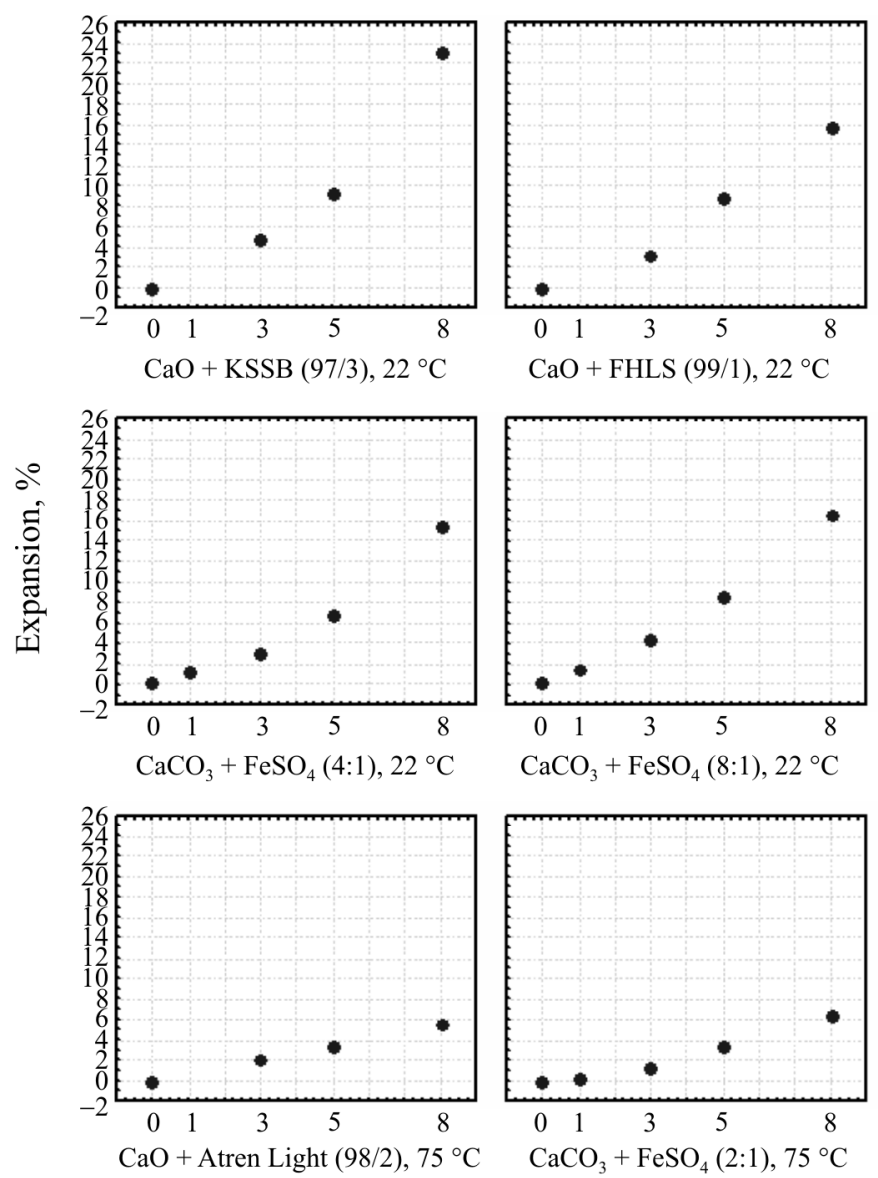

called resultant while independent is called factorial. Usually several factors influence a dependent variable. Cumulative influence of all independent factors on the dependent variable is taken into account thanks to multiple regression.
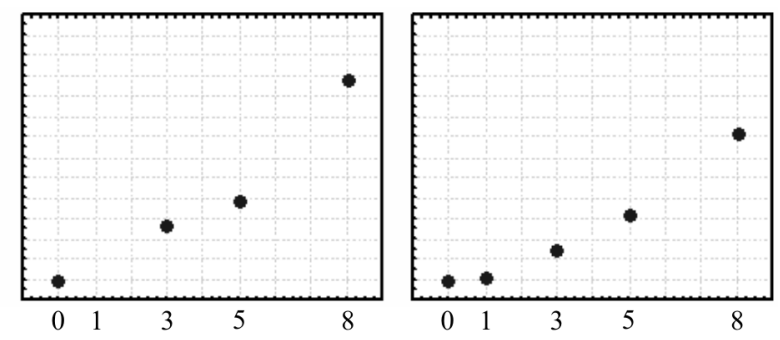

$\mathrm{CaO}+$ Atren Light $(98 / 2), 22^{\circ} \mathrm{C}$
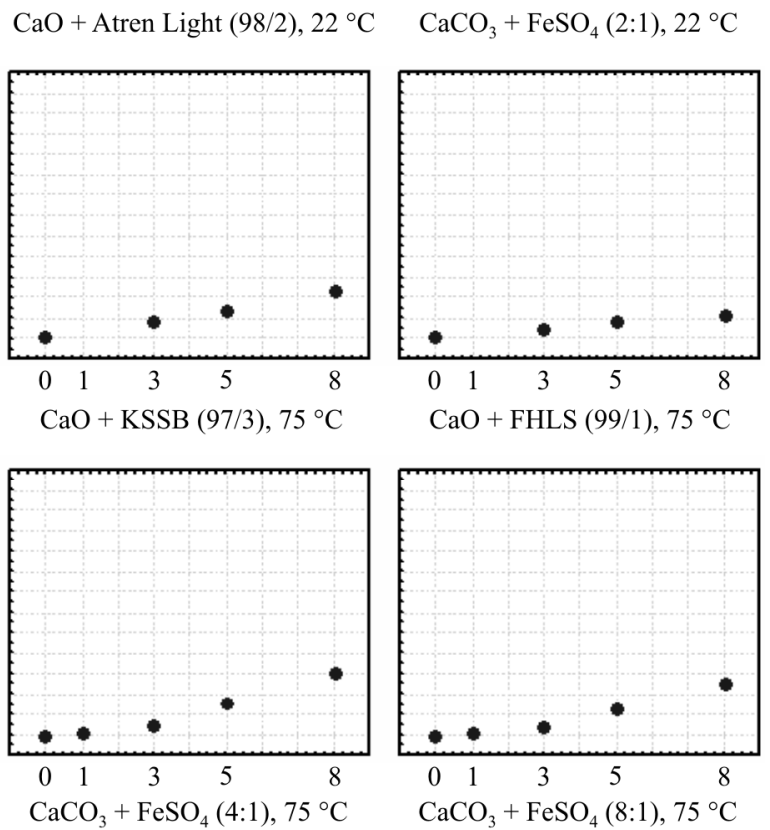

Concentration, $\%$

Fig. 1. Dependency $P_{l}$ from $t$ and $C$

In a general case multiple regression is evaluated by parameters of a linear equation such as

$$
Y=a+b_{1} X_{1}+b_{2} X_{2}+\ldots+b_{p} X_{p} .
$$

Here regression coefficients ( $b$-coefficients) represent independent contributions of each independent variable to the prediction of a dependent variable. Regression line expresses the best prediction of a dependent variable $(Y)$ over independent variables $(X)$.

In our case, PI represents a dependent feature and values $t$ and $C$ are independent factors.

Multidimensional models are constructed for seven options (Table 4). The first multidimensional model is constructed from data taking into account different values for both $t$ and $C$. The remaining six models were constructed individually for the additives studied.
Table 4

Multidimensional models for calculation of model values of linear expansion $\left(P_{l m}\right)$

\begin{tabular}{|c|c|c|c|c|}
\hline \multirow[t]{2}{*}{ Models } & \multirow[t]{2}{*}{$\begin{array}{c}\text { Free term - } \\
\text { numerator, } \\
p \text { - denominator }\end{array}$} & \multicolumn{2}{|c|}{$\begin{array}{c}\text { Coefficients of } \\
\text { indexes - numerator, } \\
p \text {-denominator }\end{array}$} & \multirow{2}{*}{$\begin{array}{c}R- \\
\text { numerator, } \\
p- \\
\text { denominator }\end{array}$} \\
\hline & & $C$ & $t$ & \\
\hline \multirow{2}{*}{ All data } & 3.3 & 1.396944 & -0.08633 & 0.863 \\
\hline & $\overline{0.0}$ & $\overline{0.000000}$ & $\overline{0.000000}$ & $<0 . \overline{000000}$ \\
\hline \multirow{2}{*}{$\begin{array}{l}\mathrm{CaO}+\mathrm{KSSB} \\
(97 / 3)\end{array}$} & 5.3 & 1.713235 & -0.13207 & $\underline{0.851}$ \\
\hline & 0. & $\overline{0.031010}$ & $\overline{0.091594}$ & $<\overline{0.03962}$ \\
\hline \multirow{2}{*}{$\begin{array}{l}\mathrm{CaO}+\mathrm{FHLS} \\
(99 / 1)\end{array}$} & 4.6687 & 1.135294 & -0.10613 & $\underline{0.858}$ \\
\hline & 569 & 0.035936 & 0.001606 & $<0.03571$ \\
\hline \multirow{2}{*}{$\begin{array}{l}\mathrm{CaO}+\text { Atren } \\
\text { light }(98 / 2)\end{array}$} & 4.176637 & 1.523529 & -0.10094 & $\underline{0.880}$ \\
\hline & 0.238292 & $\overline{0.016314}$ & $\overline{0.085266}$ & $<\overline{0.02404}$ \\
\hline \multirow{2}{*}{$\begin{array}{l}\mathrm{CaCO}_{3}+ \\
\mathrm{FeSO}_{4}(2: 1)\end{array}$} & 1.376224 & 1.302864 & -0.04845 & 0.921 \\
\hline & 0.393286 & 0.000583 & $\overline{0.081266}$ & $<\overline{0.00134}$ \\
\hline \multirow{2}{*}{\begin{tabular}{|l|}
$\mathrm{CaCO}_{3}+$ \\
$\mathrm{FeSO}_{4}(8: 1)$ \\
\end{tabular}} & 2.110877 & 1.330097 & -0.06150 & $\underline{0.909}$ \\
\hline & & 0.001078 & 0.056744 & $<\overline{0.00211}$ \\
\hline \multirow{2}{*}{$\begin{array}{l}\mathrm{CaCO}_{3}+ \\
\mathrm{FeSO}_{4}(8: 1) \\
\end{array}$} & 3.424721 & 1.353883 & -0.08491 & $\underline{0.909}$ \\
\hline & $\overline{0.121019}$ & $\overline{0.001961}$ & 0.027288 & $<\overline{0.00211}$ \\
\hline
\end{tabular}


That is follows from the analysis of equations that the quantity of $P_{l \mathrm{~m}}$ is formed for all the models by a fairly similar mechanism. In all the cases $C$ is included at the first stage of model construction and $t$ at the second stage. Graphical representation of $P_{l \mathrm{~m}}$ values model construction from all data as a function of $t$ and $C$ is shown in the Fig. 2. It is clear that during the construction of the model using all the data values of both the free term and the regression coefficients for $C$ and $t$ are statistically significant. Here it should be noted that the "contribution" of the influence of the index $C$ is greater than $t$. For other models, this trend is also observed. $P_{l m}$ values $C$ in comparison with $t$. Note, that for two options indexes of $C$ and $t$ are statistically significant $\mathrm{CaO}+\mathrm{FHLS}(99 / 1)$ и $\mathrm{CaCO}_{3}+\mathrm{FeSO}_{4}(8: 1)$.

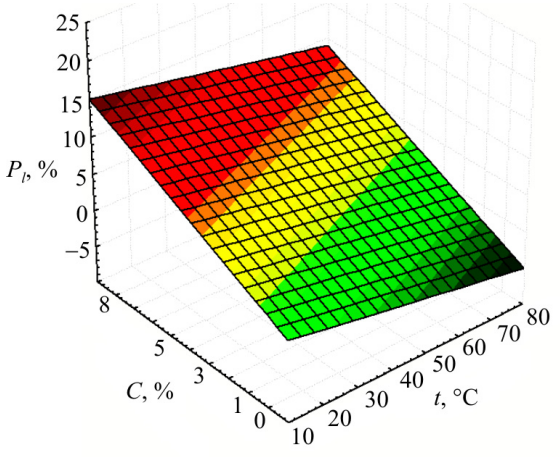

Fig. 2. Dependence of $P_{l}$ from $t$ and $C$

Based on the models given above model values of $P_{l m}$ were calculated and then compared with experimental values of $P_{l}$. Note that comparison is performed for two options. The firs options consider all the data of $P_{l m 1}$. The second one considers six models built on different additives, $P_{l m 2}$. Correlation fields between $P_{l}$ and $P_{l m 1}, P_{l}$ and $P_{l m 2}$ are given in Fig. 3 .



Fig. 3. Correlation fields between $P_{l}$ and $P_{l m 1}, P_{l m 2}$
Based on that for the ration of $P_{l}$ and $P_{l m 1}$ a correlation field consists of three parts such as $P_{l m 1}<0 \%$ for the first subfield, $0<P_{l m 1}<10 \%$ for the second subfield and $P_{l m 1}>10 \%$ for the third subfield. There is no correlation for the first and third subfields between the $P_{l}$ and $P_{l m 1}$. There is a significant correlation link observed for the second subfield. Here it should be noted that for the third subfield change in values of $P_{l m 1}$ are constant. This proves that mentioned values do not depend on the values of $t$ and $C$. In this case real values of $P_{l}$ are greater than the model ones computed from the above model. Correlation field between $P_{l}$ and $P_{l m 2}$ also consists of three parts such as the first subfield with the values $P_{\operatorname{lm} 2}<0 \%$, the second subfield with values $0<P_{\operatorname{lm} 2}<10 \%$ and the third subfield with values $P_{l m 2}>10 \%$. There are no correlation links observed between the $P_{l}$ and $P_{l m 1}$ for the first subfield and significant correlation links between the second and third subfield. Moreover, the second subfield has correlative link while third subfield has almost functional link. The correlation field was visually devided into classes mentioned above. In order to prove this step statistical calculations age given below. For that, a linear discriminant analysis (LDA) is used. Frequently scientists use LDA in their works to describe processes that occurre in wells and formations [27-30].

Linear discriminant functions (LDF) are calculated using visually selected sections of the correlation field. Construction of a linear discriminant function is presented next. If $X_{i j}$ means $P_{l}, P_{l m 1}$ with a number $i$ at the point of observation with number $j$, obtained in the first part of the correlation field (group 1), then a matrix $W_{1}$ of $m$ and $n_{1}$ decade can be obtained. Results of observations over this sample are:

$$
W_{1}=\left[\begin{array}{cccc}
X_{11} & X_{12} & \cdot & X_{1 n_{1}} \\
X_{21} & X_{22} & \cdot & X_{2 n_{1}} \\
\cdot & \cdot & \cdot & \cdot \\
X_{m 1} & X_{m 2} & \cdot & X_{m n_{1}}
\end{array}\right] .
$$

Define $X_{i j}^{1}$ for $P_{l}$ and $P_{l m 1}$ values with a number $i$ at the point with number $j$ from the sample in the second part of a correlation field (group 2). Then we get a matrix $W_{2}$ of $m \times n_{2}$ decade:

$$
W_{2}=\left[\begin{array}{cccc}
X_{11}^{1} & X_{12}^{1} & \cdot & X_{1 n_{2}} \\
X_{21}^{1} & X_{22}^{1} & \cdot & X_{2 n_{2}}^{1} \\
\cdot & \cdot & \cdot & \cdot \\
X_{m 1}^{1} & X_{m 2}^{1} & \cdot & X_{m n_{2}}^{1}
\end{array}\right] .
$$


Define $X^{2}{ }_{i j}$ for $P_{l}$ and $P_{l m 1}$ values with a number $i$ at the point with number $j$, taken from the sample of the third part of a correlation field. Then we get a matrix $W_{3}$ of $m \times n_{2}$ decade

$$
W_{3}=\left[\begin{array}{cccc}
X_{11}^{2} & X_{12}^{2} & \cdot & X_{1 n_{2}} \\
X_{21}^{2} & X_{22}^{21} & \cdot & X_{2 n_{2}}^{2} \\
\cdot & \cdot & \cdot & \cdot \\
X_{m 1}^{2} & X_{m 2}^{2} & \cdot & X_{m n_{2}}^{2}
\end{array}\right],
$$

where $m$ is a number of indexes; $n_{1}, n_{2}, n_{3}$ are amount of samples.

In order to construct LDF matrixes of centered sums of squares and mixed multiplicatios are compiled. They are used to calculate a sample matrix. Then, to determine coefficients of a linear discriminant function an inverse selective covariance matrix-matrix $C$ is obtained. Then boundary values of discriminant functions $\left(R_{0}\right)$ are calculated. Those values divide the sample into three subsets. Reliability of classification is calculated using the Pearson test $\chi^{2}$.

As a result of calculations, linear discriminant functions are obtained. Based on them the sample is completely divided into three classes such as

$$
Z_{1}=-0.385196 \cdot P_{l}-0.017049 \cdot P_{l m l}+1.724032
$$

when $R=0.891, \chi^{2}=122.4797, p=0.000000$;

$$
Z_{2}=0.464922 \cdot P_{l}-0.614475 \cdot P_{l m l}+0.530864
$$

when $R=0.432, \chi^{2}=42.3717, p=0.000000$.

Using equations given above values of $Z_{1}$ and $Z_{2}$ are caltulated (Fig. 4).

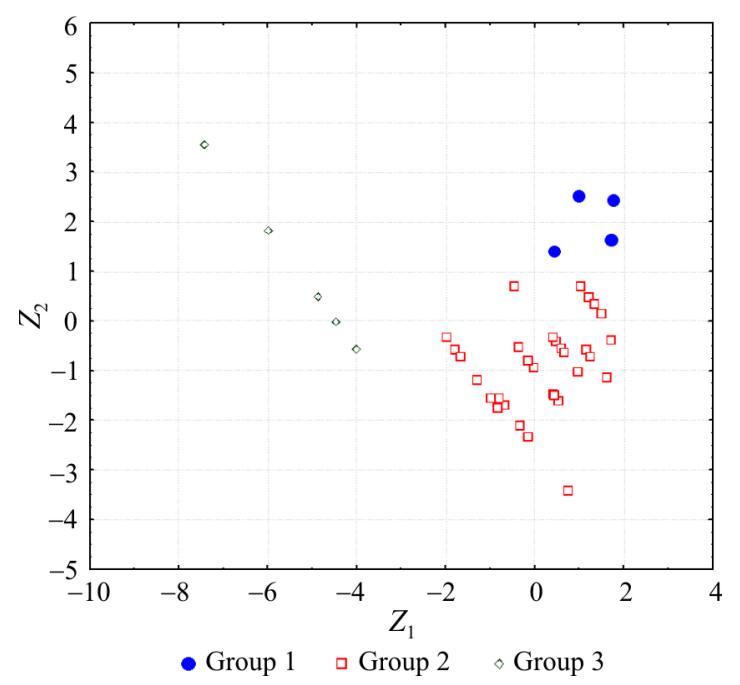

Fig. 4. Values of $Z_{1}$ and $Z_{2}$ in groups
It is clear that using values of $P_{l}$ and $P_{l m 1}$ built LDF devide the sample into three disjoint groups. Mean values of $Z_{1}$ and $Z_{2}$ on the selected classes are given in the Table 5 .

Table 5

Statistical characteristics of values $Z_{1}$ and $Z_{2}$

\begin{tabular}{|c|c|c|c|}
\hline \multirow{2}{*}{ Indexes } & \multicolumn{3}{|c|}{ Mean values of indexes } \\
\cline { 2 - 4 } & Group 1 & Group 2 & Group 3 \\
\hline$Z_{1}$ & 1.682 & 0.344 & -5.206 \\
\hline$Z_{2}$ & -1.993 & -0.728 & 0.872 \\
\hline
\end{tabular}

An analysis of distribution of values on the additives shows that for the additive $\mathrm{CaO}+\mathrm{KSSB}(97 / 3)$ at $t=22{ }^{\circ} \mathrm{C}$ expansion in the range of $0-9,3 \%$ occurs according to the model that belongs to the second group, at $23.2 \%$ it belongs to the third group and at $t=75{ }^{\circ} \mathrm{C}$ with concentration of $0 \%$ to the first group. All others belong to the secon group. For the additive $\mathrm{CaO}+\mathrm{FHLS}(99 / 1)$ at $t=22{ }^{\circ} \mathrm{C}$ expansion in the range of $0-8,8 \%$ occure according to the model that belongs to the second group, at $15.5 \%$ it belongs to the third group, at $t=75{ }^{\circ} \mathrm{C}$ with concentration of $0 \%$ it belongs to the first group, all others belong to the second group. For the additive $\mathrm{CaO}+$ Atren Light $(98 / 2)$ at $t=22{ }^{\circ} \mathrm{C}$ expansion in the range of $0-7.5 \%$ occure according to the model that belongs to the second group, at $19.5 \%$ it belongs to the third group, at $t=75^{\circ} \mathrm{C}$ with concentration of $0-3.3 \%$ it belongs to the first group, with concentration of $5.5 \%$ all others belong to the second group. For the additive $\mathrm{CaCO}_{3}+\mathrm{FeSO}_{4}(2: 1)$ at $t=22{ }^{\circ} \mathrm{C}$ expansion in the range of $0-6.3 \%$ occure according to the model that belongs to the second group, at $14.3 \%$ it belongs to the third group, at $t=75{ }^{\circ} \mathrm{C}$ with concentration $0-0.06 \%$ it belongs to the first group, all others belong to the second group. For the additive $\mathrm{CaCO}_{3}+\mathrm{FeSO}_{4}(4: 1)$ expansion in the range of $0-6.7 \%$ occure according to the model that belongs to the second group, at $15.5 \%$ it belongs to the third group, at $t=75^{\circ} \mathrm{C}$ expansion in the range of $0-0.1 \%$ it belongs to the first group, all others belong to the second group. For the additive $\mathrm{CaCO}_{3}+\mathrm{FeSO}_{4}(8: 1)$ at $t=22{ }^{\circ} \mathrm{C}$ expansion in the range of $0-8.5 \%$ occure according to the model that belongs to the second group, at $16.6 \%$ it belongs to the third group, at $t=75^{\circ} \mathrm{C}$ expansion in the range of $0-0.1 \%$ it belongs to the first group, all others belong to the second group. All this shows that processes of expansion due to $C$ and $t$ have both 
general trends and certain deviations from them. Deviations from the regular values of $P_{l}$ as a function of $C$ and $t$ are more frequent for the first and third groups. The share of groups is as follows: $20.4 \%$ for the first group, all refers to the data at $t=75{ }^{\circ} \mathrm{C}, 68.5 \%$ for the second group, $11.1 \%$ for the third group. All this indicates that processes that form values of $P_{i}$ in the groups occur according to various mechanisms. Therefore we will construct refined multidimensional models for calculation of values of $P_{l m 1}$ with considered three classes that were selected (Table 6).

Table 6

Multidimensional models for calculation of $P_{l m 1}$

\begin{tabular}{|c|c|c|c|c|}
\hline \multirow[t]{2}{*}{ Models } & \multirow{2}{*}{$\begin{array}{c}\text { Free term- } \\
\text { numerator, } \\
p-\text { denominator }\end{array}$} & \multicolumn{2}{|c|}{$\begin{array}{c}\text { Coefficients of indexes } \\
\text { - numerator, } \\
p \text {-denominator }\end{array}$} & \multirow{2}{*}{$\begin{array}{c}R- \\
\text { numerator, } \\
p- \\
\text { denominator }\end{array}$} \\
\hline & & $C$ & $t$ & \\
\hline Group 1 & $\frac{-0.465385}{0.122060}$ & $\frac{0.728846}{0.000000}$ & - & $<\frac{0.964}{<0.000000}$ \\
\hline Group 2 & $\frac{2.392259}{0.000052}$ & $\frac{1.288030}{0.000000}$ & $\frac{-0.09269}{0.000000}$ & $<\underline{0.897}$ \\
\hline Group 3 & $\underline{16.54219}$ & $\underline{0.73848}$ & $\frac{-0.22803}{0.000000}$ & $<\frac{0.858}{0.03571}$ \\
\hline
\end{tabular}

Analysis of these equations shows that the value of $P_{l m 1}$ is formed for all models individually. For the first group the value of $P_{l m 1}$ is formed only as a function of $\mathrm{C}$, since the value of $t$ in all the cases $75{ }^{\circ} \mathrm{C}$. For the second group, the model begins to form from $C$ and then in the second step from $t$. For the third group there is an inversion with respect to the second group, since the formation of the model begins with $t$ and with $C$ in the second step. Model values of $P_{l m 1}$ were calculated using equeations given above and then compared with the real values (Fig. 5a).

A similar analysis can be performed using the value of $P_{\operatorname{lm} 2}$. As a result of calculations, linear discriminant functions given below are obtained. According to that the sample is completely divided into three classes such as

$$
Z_{11}=0.1351291 \cdot P_{l}-0.630147 \cdot P_{l m 2}+2.105323
$$

when $R=0.927, \chi^{2}=102.6903, p=0.000000$;

$$
Z_{22}=0.711738 \cdot P_{l}-0.694227 \cdot P_{l m 2}-0.096605
$$

when $R=0.249, \chi^{2}=3.2346, p=0.072098$.

According to mentioned formulas values of $Z_{1}$ were calculated, probabilities of belonging to the group $Z_{2}$ were determined, the relationship between which is shown in Fig. 6 .

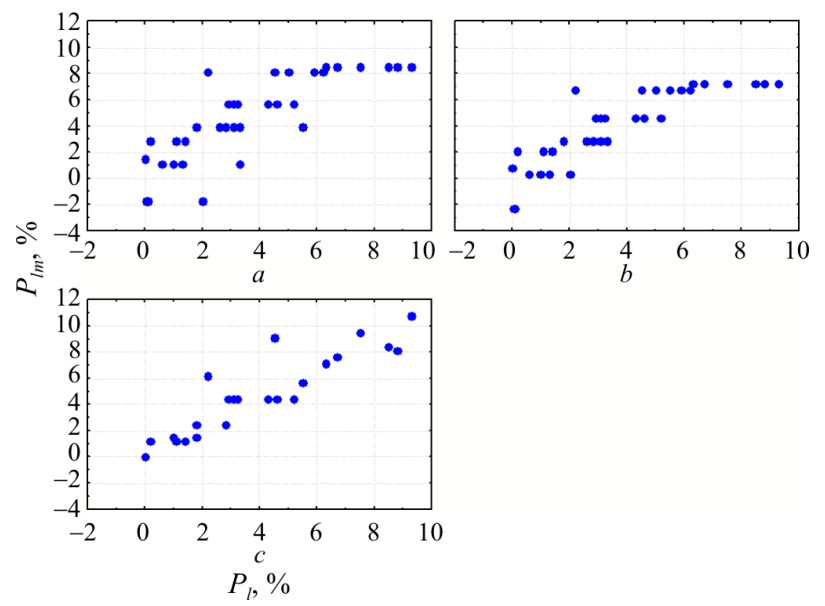

Fig. 5. Correlation fields between $P_{l}$ and $P_{l m 1}, P_{l m 2}, P_{l m 22}$

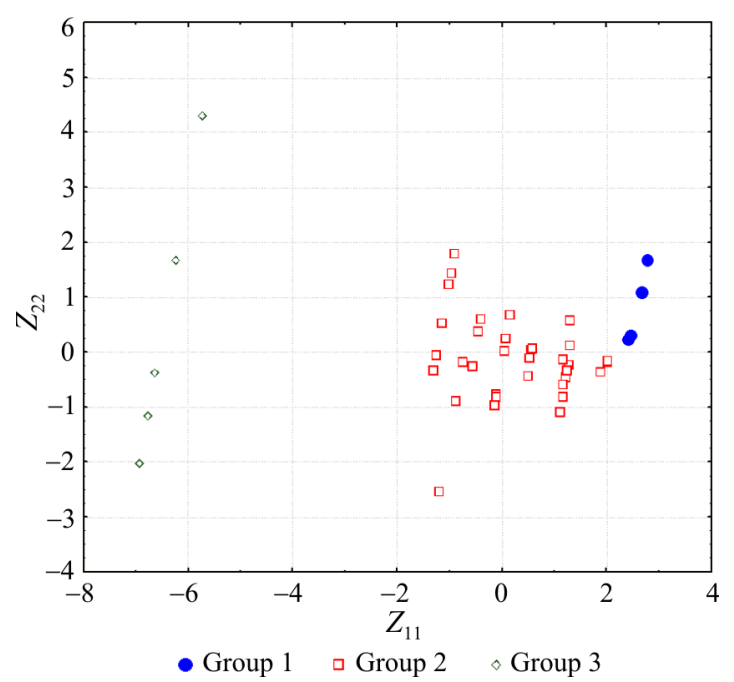

Fig. 6. Values $Z_{11}$ and $Z_{22}$ in groups

It is clear that with use of the values of $P_{l}$ and $P_{l m 2}$ built LDF devide the sample into the three disjoint groups. Mean values of $Z_{1}$ and $Z_{2}$ for the selected classes are shown in Table 7.

Table 7

Statistical characteristics of values $Z_{11}$ and $Z_{22}$

\begin{tabular}{|c|c|c|c|}
\hline \multirow{2}{*}{ Indexes } & \multicolumn{3}{|c|}{ Mean values of indexes } \\
\cline { 2 - 4 } & Group 1 & Group 2 & Group 3 \\
\hline$Z_{11}$ & 2.504 & 0.477 & -6.521 \\
\hline$Z_{22}$ & 0.540 & -0.139 & 0.208 \\
\hline
\end{tabular}

All this allows to consider that it is possible to construct refined multidimensional models for calculating the values of $P_{\operatorname{lm} 2}$ with the three considered groups (Table 8). Here it should be noted that comparison of model and real values can be made only by group 2 . Since the value of $t$ does not change it is not possible to construct models for groups 1,3 . 
Table 8

Multidimensional models for calculations $P_{\operatorname{lm} 2}$

\begin{tabular}{|c|c|c|c|c|}
\hline \multirow[t]{2}{*}{ Models } & \multirow[t]{2}{*}{$\begin{array}{c}\text { Free term- } \\
\text { numerator, } \\
p \text { - denominator }\end{array}$} & \multicolumn{2}{|c|}{$\begin{array}{c}\text { Coefficients of } \\
\text { indexes - numerator, } \\
p \text {-denominator }\end{array}$} & \multirow{2}{*}{$\begin{array}{c}R- \\
\text { numerator, } \\
p- \\
\text { denominator }\end{array}$} \\
\hline & & $C$ & $t$ & \\
\hline Group 2 & $\frac{2.553451}{0.000507}$ & $\frac{1.293490}{0.000000}$ & $\frac{-0.08242}{0.000000}$ & $<\frac{\underline{0.854}}{<.000000}$ \\
\hline
\end{tabular}

Analysis of these equations shows that the value of $P_{l m 2}$ is formed as it given next. At the first step, value of $C$ is included to the model and $t$ at the second step. According to this formula, the values of $P_{l m 2}$ were calculated and compared with $P_{l}$ (Fig. $5 b$ )

It is clear that for the ratio of $P_{l}$ and $P_{l m 1}$ correlation link $(r=0.84)$ is less tight than for $P_{l}$ and $P_{\operatorname{lm} 2}(r=0.88)$.

Thus, the analysis performed shows, that at first, formation of values $P_{l m l}$ in the range of 1-6\% indeed occurs depending on $C$ and $t$, then in the range of $6-10 \%$ the process occures by synergistic effect of joint influence $C$ and $t$. In order to calculate its joint influence we will construct a more complex statistical model. That model, in our opinion, will describe not only the influence $C$ and $t$ individually for $P_{l}$, but their combined effect in the range of $0-10 \%$. The proposed model is as follows:

$$
\begin{aligned}
& P_{\operatorname{lm} 22}=0.0728+1.7485 \cdot \mathrm{C}-0.0143 \cdot t+ \\
& +0.1207 \cdot \mathrm{C}^{2}-0.0297 \cdot \mathrm{C} \cdot t+0.0005 \cdot t^{2}
\end{aligned}
$$

when $R^{2}=0.975$.

Using a relationship given above the values of $P_{l m 22}$ were correlated and compared with values of $P_{l}$. The correlation field between $P_{l}$ and $P_{l m 22}$ is given on the Fig. $5 c$. It is seen that this dependence describes the effect of $C$ and $t$ on $P_{l}$ much better than in the first two cases $(r=0.97)$.

Secondly, despite the general nature of the processes, that was proved above, there are specific deviations for each of the cases considered. This fact should be used for practical purposes in order to choose an expanding additive for cement slurries.

\section{Conclusion}

In the conditions of moderate temperatures the greatest expansion was obtained with use of dicalcium ferrite with calcium oxide. Under the normal temperature that effect was obtained with use of calcium oxide and an inhibitor.

Mathematical means and statistical data processing allowed creating the mathematical model of the effect of expanding additive temperature and concentration on the degree of cement slurry expansion.

\section{References}

1. Mazurok P.S. Vliianie tsementirovaniia neftianykh i gazovykh skvazhin na ekonomiku [The influence of cementing oil and gas wells on the economy]. Burenie $i$ neft', 2015, no.12, pp.32-35.

2. Boukhelifa L., Moroni N., James S.G., Le RoyDelage S., Thiercelin M.J., Lemaire G. Evaluation of cement systems for oil- and gas-well zonal isolation in a full-scale annular geometry. SPE Drilling and Completion, 2005, 20(1), pp.44-53. DOI: 10.2118/87195-PA

3. Krusche K., Johnson C.R., Braud N.Y., Ghazi H.B. Application of engineered cementing solution to solve long-term cement integrity issues in Tunisia. SPE Annual Technical Conference and Exhibition. Paper presented at the Proceedings. San Antonio, 2006, pp.77-85. DOI: $10.2118 / 100390-\mathrm{MS}$

4. Bulatov A.I. Detektivnaia biografiia germetichnosti krepi neftianykh i gazovykh skvazhin [Detective biography of hermetic sealing of oil and gas wells]. Krasnodar, Prosveshchenie-Iug, 2009, 934 p.

5. Bulatov A.I. Kontseptsiia kachestva proburennykh neftianykh i gazovykh skvazhin [The concept of quality of oil and gas wells drilled]. Burenie $i$ neft', 2015, no.12, pp.15-19.

6. Bulatov A.I. O kachestve proburennoi skvazhiny i ee krepi [Regarding the quality of a drilled well and its lining]. Burenie i neft', 2015, no.10, pp.10-12.

7. Bulatov A.I. Chto predstavliaet soboi zatsementirovannoe zakolonnoe prostranstvo [What is cemented over the columned space]. Burenie $i$ neft', 2016, no.6, pp.30-34.
8. Chernyshev S.E., Krapivina T.N. Influence of expansion agent on properties of cement slurry-stone. Bulletin of Perm National Research Polytechnic University. Geology. Oil \& Gas Engineering \& Mining, 2010, no.5, pp.31-33.

9. Kozhevnikov E.V. Study of properties of cement slurries for horizontal well and sidetrack cementing. Bulletin of Perm National Research Polytechnic University. Geology. Oil \& Gas Engineering \& Mining, 2015, no.17, pp.24-31. DOI: $10.15593 / 2224-9923 / 2015.17 .3$

10. Mangadlao J.D., Cao P., Advincula R. C. Smart cements and cement additives for oil and gas operations. Journal of Petroleum Science and Engineering, 2015, 129, pp.63-76. DOI: 10.1016/j.petrol.2015.02.009

11. Raki L., Beaudoin J., Alizadeh R., Makar J., Sato T. Cement and concrete nanoscience and nanotechnology. Materials, 2010, 3(2), pp.918-942. DOI: 10.3390/ma3020918

12. Nikolaev N.I., Kozhevnikov E.V. Enhancing the cementing quality of the well with horizontal profile. Bulletin of Perm National Research Polytechnic University. Geology. Oil \& Gas Engineering \& Mining, 2014, no.11, pp.29-37. DOI: $10.15593 / 2224-9923 / 2014.11 .3$

13. Cheung P.S. Expanding additive for cement composition. Patent no. 5,942,031.

14. Thomas J., Musso S., Catheline S., Chougnet-Sirapian A., Allouche M. Expanding cement for improved wellbore sealing: Prestress development, physical properties, and logging response. SPE Deepwater Drilling and Completions Conference. Paper presented at the Society of Petroleum Engineers, 2014, pp.506-515. DOI: 10.2118/170306-MS. 
15. Krivoshei A.V. Razrabotka rasshiriaiushchikhsia tamponazhnykh smesei dlia nizkikh i umerennykh temperatur [Development of expanding grouting mixtures for low and moderate temperatures]. Neftianoe khoziaistvo, 2005, no.4, pp.36-37.

16. Kunitskikh A.A. Issledovanie modifitsiruiushchikh dobavok $\mathrm{k}$ tamponazhnym rastvoram [Investigation of modifying additives to grouting mortars]. Neftianoe khoziaistvo, 2016, no.5, pp.46-50.

17. Analiz kachestva krepleniia vtoroi stupeni po opytnym skvazhinam. Razrabotka retseptury rasshiriaiushchegosia tamponazhnogo tsementa dlia krepleniia produktivnoi chasti skvazhin [Analysis of the quality of fastening of the second stage on the experimental wells. Development of a recipe for expanding oil well cement for fixing the productive part of wells]. Otchet o NIR po dogovoru №63.01.150.22/17-364. Kogalym, KogalymNIPIneft', 2002.

18. Odler I., Colán-Subauste J. Investigations on cement expansion associated with ettringite formation. Cement and Concrete Research, 1999, 29(5), pp.731-735. DOI: 10.1016/S0008-8846(99)00048-4

19. Zhu H.J., Hua S.D., Wu Q.S., Zhang C.S., Yang T. Effect of $\mathrm{MgO}$ expanding agent on early performance of oil well cement under three dimensional constraint. Zhongguo Shiyou Daxue Xuebao (Ziran Kexue Ban). Journal of China University of Petroleum (Edition of Natural Science), 2013, 37(6), pp.153-158. DOI: 10.3969/j.issn.1673-5005.2013.06.025

20. Chernyshchov S.E. et al. Issledovanie rasshiriaiushchei sposobnosti tamponazhnykh sostavov na osnove portlandtsementov [Study of the expanding ability of oil-based compositions based on Portland cement]. Neftianoe khoziaistvo, 2013, no.11, pp.104-106.

21. Dulu A., Peter R. Practical improvements in CaO-swelling cements. Journal of Petroleumx Science and Engineering, 2002, 36, pp.61-70. DOI: $10.1016 / \mathrm{S} 0920-4105(02) 00251-6$

22. Chatterji S. Mechanism of expansion of concrete due to the presence of dead-burnt $\mathrm{CaO}$ and $\mathrm{MgO}$. Cement and Concrete Research, 1995, 25(1), pp.51-56. DOI: 10.1016/0008-8846(94)00111-B

23. Agzamov F.A., Babkov V.V., Karimov I.N. O neobkhodimoi velichine rasshireniia tamponazhnykh materialov [About the required amount of expansion of plugging materials]. Territoriia neftegaz, 2011, no.8, pp.14-15.

24. Kunitskikh A.A. Research and development of expansion agents for grouting mortars. Bulletin of Perm National Research Polytechnic University. Geology. Oil \& Gas Engineering \& Mining, 2015, no.16, pp.46-53. DOI: $10.15593 / 2224-9923 / 2015.16 .5$.

25. Sorokin L.A. Razrabotka rasshiriaiushchikhsia tamponazhnykh tsementov dlia povysheniia kachestva tsementirovaniia skvazhin $\mathrm{v}$ intervale temperatur $60-120{ }^{\circ} \mathrm{C}$ 「Development of expanding oil-well cement to improve the quality of well cementing in the temperature range 60-120 ${ }^{\circ} \mathrm{C}$ ]. Abstract of Ph. D. thesis. Moscow, 2005, 20 p.

26. Kunitskikh A.A., Chernyshov S.E., Votinov M.V. Issledovanie dinamiki gidratatsii i razrabotka sostavov rasshiriaiushchikh dobavok $\mathrm{k}$ tamponazhnym rastvoram [The study of the dynamics of hydration and the development of formulations of expanding additives to grouting mortars]. Neftianoe khoziaistvo, 2015, no.8, pp.42-44.

27. Avetisov A.G., Bulatov A.I., Shamanov S.A. Metody prikladnoi matematiki $\mathrm{V}$ inzhenernom dele pri stroitel'stve neftianykh i gazovykh skvazhin [Methods of applied mathematics in engineering for the construction of oil and gas wells]. Moscow, Nedra-Biznestsentr, 2003, $239 \mathrm{p}$.

28. Galkin V.I., Ponomareva I.N., Repina V.A. Study of oil recovery from reservoirs of different void types with use of multidimensional statistical analysis. Bulletin of Perm National Research Polytechnic University. Geology. Oil \& Gas Engineering \& Mining, 2016, no.19, pp.145-154. DOI: 10.15593/2224-9923/2016.19.5.

29. Andreiko S.S. Development of mathematical model of gas-dynamic phenomena forecasting method according to geological data in conditions of Verkhnekamskoie potash salt deposit. Bulletin of Perm National Research Polytechnic University. Geology. Oil \& Gas Engineering \& Mining, 2016, no.21, pp.345-353. DOI: $10.15593 / 2224-9923 / 2016.21 .6$

30. Chernykh I.A. Determination of bottomhole pressure by using multivariate statistical models (on example of formation TL-BB Yurchukskoie field). Bulletin of Perm National Research Polytechnic University. Geology. Oil \& Gas Engineering \& Mining, 2016, no.21, pp.320-328. DOI: $10.15593 / 2224-9923 / 2016.21 .3$

\section{Библиографический список}

1. Мазурок П.С. Влияние цементирования нефтяных и газовых скважин на экономику // Бурение и нефть. - 2015. - № 12. - С. 32-35.

2. Evaluation of cement systems for oil- and gas-well zonal isolation in a full-scale annular geometry / L. Boukhelifa, N. Moroni, S.G. James, S. Le Roy-Delage, M.J. Thiercelin, G. Lemaire // SPE Drilling and Completion. - 2005. № 20 (1). - P. 44-53. DOI: 10.2118/87195-PA

3. Application of engineered cementing solution to solve long-term cement integrity issues in Tunisia / K. Krusche, C.R. Johnson, N.Y. Braud, H.B. Ghazi // SPE Annual Technical Conference and Exhibition: Paper presented at the Proceedings. - San Antonio, 2006. P. 77-85. DOI: 10.2118/100390-MS

4. Булатов А.И. Детективная биография герметичности крепи нефтяных и газовых скважин: монография. - 3-е изд. - Краснодар: Просвещение-Юг, 2009. -934 c.
5. Булатов А.И. Концепция качества пробуренных нефтяных и газовых скважин // Бурение и нефть. 2015. - № 12. - С. 15-19.

6. Булатов А.И. О качестве пробуренной скважины и ее крепи // Бурение и нефть. - 2015. - № 10. - С. 10-12.

7. Булатов А.И. Что представляет собой зацементированное заколонное пространство // Бурение и нефть. - 2016. - № 6. - С. 30-34.

8. Чернышов С.Е., Крапивина Т.Н. Влияние расширяющих добавок на свойства цементного раствора-камня // Вестник Пермского национального исследовательского политехнического университета. Геология. Нефтегазовое и горное дело. -2010. - № 5. - С. 31-33.

9. Кожевников Е.В. Исследование свойств тампонажных растворов для крепления скважин и боковых стволов с наклонными и горизонтальными участками // Вестник Пермского национального исследовательского политехнического университета. 
Геология. Нефтегазовое и горное дело. - 2015. № 17. - C. 24-31. DOI: 10.15593/2224-9923/2015.17.3

10. Mangadlao J.D., Cao P., Advincula R.C. Smart cements and cement additives for oil and gas operations // Journal of Petroleum Science and Engineering. - 2015. № 129. - P. 63-76. DOI:10.1016/j.petrol.2015.02.009

11. Cement and concrete nanoscience and nanotechnology / L. Raki, J. Beaudoin, R. Alizadeh, J. Makar, T. Sato // Materials. - 2010. - № 3 (2). P. 918-942. DOI: 10.3390/ma3020918

12. Николаев Н.И., Кожевников Е.В. Повышение качества крепления скважин с горизонтальными участками // Вестник Пермского национального исследовательского политехнического университета. Геология. Нефтегазовое и горное дело. - 2014. - № 11. C. 29-37. DOI: 10.15593/2224-9923/2014.11.3

13. Cheung P.S. Expanding additive for cement composition: patent no. 5.942.031. - 1999. - 24 Aug.

14. Expanding cement for improved wellbore sealing: Prestress development, physical properties, and logging response / J. Thomas, S. Musso, S. Catheline, A. Chougnet-Sirapian, M. Allouche // SPE Deepwater Drilling and Completions Conference: paper presented at the Society of Petroleum Engineers. - 2014. - P. 506-515. DOI: $10.2118 / 170306-\mathrm{MS}$

15. Кривошей А.В. Разработка расширяющихся тампонажных смесей для низких и умеренных температур // Нефтяное хозяйство. - 2005. - № 4. - С. 36-37.

16. Куницких А.А. Исследование модифицирующих добавок к тампонажным растворам // Нефтяное хозяйство. -2016 . - № 5. - С. 46-50.

17. Анализ качества крепления второй ступени по опытным скважинам. Разработка рецептуры расширяющегося тампонажного цемента для крепления продуктивной части скважин: отчет о НИР по договору № 63.01.150.22/17-364 / ООО «КогалымНИПИнефть». Когалым, 2002.

18. Odler I., Colán-Subauste J. Investigations on cement expansion associated with ettringite formation // Cement and Concrete Research. - 1999. - № 29 (5). P. 731-735. DOI: 10.1016/S0008-8846(99)00048-4

19. Effect of $\mathrm{MgO}$ expanding agent on early performance of oil well cement under three dimensional constraint. Zhongguo Shiyou Daxue Xuebao (Ziran Kexue Ban) / H.J. Zhu, S.D. Hua, Q.S. Wu, C.S. Zhang, T. Yang // Journal of China University of Petroleum (Edition of Natural Science). - 2013. - № 37 (6). P. 153-158. DOI: 10.3969/j.issn.1673-5005.2013.06.025

20. Исследование расширяющей способности тампонажных составов на основе портландцементов / C.Е. Чернышов [и др.] // Нефтяное хозяйство. - 2013. № 11. - С. 104-106.

21. Dulu A., Peter R. Practical improvements in $\mathrm{CaO}$-swelling cements // Journal of Petroleumx Science and Engineering. - 2002. - № 36. - P. 61-70. DOI: $10.1016 /$ S0920-4105(02)00251-6

22. Chatterji S. Mechanism of expansion of concrete due to the presence of dead-burnt $\mathrm{CaO}$ and $\mathrm{MgO} / /$ Cement and Concrete Research. - 1995. - № 25 (1). - P. 51-56. DOI:10.1016/0008-8846(94)00111-B

23. Агзамов Ф.А., Бабков В.В., Каримов И.Н. О необходимой величине расширения тампонажных материалов // Территория нефтегаз. - 2011. - № 8. C. $14-15$.

24. Куницких А.А. Исследование и разработка расширяющих добавок для тампонажных составов // Вестник Пермского национального исследовательского политехнического университета. Геология. Нефтегазовое и горное дело. - 2015. - № 16. - С. 46-53. DOI: $10.15593 / 2224-9923 / 2015.16 .5$

25. Сорокин Л.А. Разработка расширяющихся тампонажных цементов для повышения качества цементирования скважин в интервале температур 60$120{ }^{\circ} \mathrm{C}$ : автореф. дис. ... канд. техн. наук / Моск. гос. геологоразвед. ун-т. - М., 2005. - 20 c.

26. Куницких А.А., Чернышов С.Е., Вотинов М.В. Исследование динамики гидратации и разработка составов расширяющих добавок к тампонажным растворам // Нефтяное хозяйство. - 2015. - № 8. C. 42-44.

27. Аветисов А.Г., Булатов А.И., Шаманов С.А. Методы прикладной математики в инженерном деле при строительстве нефтяных и газовых скважин. - М.: Недра-Бизнесцентр, 2003. - 239 с.

28. Галкин В.И., Пономарева И.Н., Репина В.А. Исследование процесса нефтеизвлечения в коллекторах различного типа пустотности с использованием многомерного статистического анализа // Вестник Пермского национального исследовательского политехнического университета. Геология. Нефтегазовое и горное дело. - 2016. - № 19. - С. 145-154. DOI: $10.15593 / 2224-9923 / 2016.19 .5$

29. Андрейко С.С. Разработка математической модели метода прогнозирования газодинамических явлений по геологическим данным для условий Верхнекамского месторождения калийных солей // Вестник Пермского национального исследовательского политехнического университета. Геология. Нефтегазовое и горное дело. - 2016. - № 21. C. 345-353. DOI: 10.15593/2224-9923/2016.21.6

30. Черных И.А. Определение забойного давления с помощью многомерных статистических моделей (на примере пласта ТЛ-ББ Юрчукского месторождения) // Вестник Пермского национального исследовательского политехнического университета. Геология. Нефтегазовое и горное дело. - 2016. - № 21. C. 320-328. DOI: $10.15593 / 2224-9923 / 2016.21 .3$

Please cite this article in English as:

Galkin V.I., Kunitskikh A.A. Statistical modelling of expanding cement slurry. Perm Journal of Petroleum and Mining Engineering, 2017, vol.16, no.3, pp.215-224. DOI: 10.15593/2224-9923/2017.3.2

Просьба ссылаться на эту статью в русскоязычных источниках следующим образом:

Галкин В.И., Куницких А.А. Статистическое моделирование расширяющегося тампонажного состава // Вестник Пермского национального исследовательского политехнического университета. Геология. Нефтегазовое и горное дело. - 2017. - Т.16, №3. C.215-224. DOI: $10.15593 / 2224-9923 / 2017.3 .2$ 